\title{
Gene expression patterns of chemoresistant and chemosensitive serous epithelial ovarian tumors with possible predictive value in response to initial chemotherapy
}

\author{
DIMCHO BACHVAROV ${ }^{1,4}$, SYLVAIN L'ESPERANCE $^{1,4}$, ION POPA $^{3,4}$, MAGDALENA BACHVAROVA $^{4}$, \\ MARIE PLANTE ${ }^{2,4}$ and BERNARD TÊTU ${ }^{3,4}$ \\ Departments of ${ }^{1}$ Medicine and ${ }^{2}$ Obstetrics and Gynecology, ${ }^{3}$ Division of Pathology, Faculty of Medicine, \\ Laval University, Québec G1K 7P4; ${ }^{4}$ Cancer Research Centre, Hôpital L'Hotel-Dieu de Québec, \\ Centre Hospitalier Universitaire de Québec, 9 rue McMahon, Québec G1R 2J6, Canada
}

Received April 26, 2006; Accepted June 29, 2006

\begin{abstract}
Chemotherapy (CT) resistance in ovarian cancer is broad and encompasses diverse, unrelated drugs, suggesting more than one mechanism of resistance. We aimed to analyze the gene expression patterns in primary serous epithelial ovarian cancer (EOC) samples displaying different responses to first-line CT in an attempt to identify specific molecular signatures associated with response to CT. Initially, the expression profiles of 15 chemoresistant serous EOC tumors [time to recurrence (TTR) $\leq 6$ months] and 10 chemosensitive serous EOC tumors (TTR $\geq 30$ months) were independently analyzed which allowed the identification of specific sets of differentially expressed genes that might be functionally implicated in the evolution of the chemoresistant or the chemosensitive phenotype. Our data suggest that the intrinsic chemoresistance in serous EOC cells may be attributed to the combined action of different molecular mechanisms and factors linked with drug influx and efflux and cell proliferation, as possible implications of other molecular events including altered metabolism, apoptosis and inflammation cannot be excluded. Next, gene expression comparison using hierarchical clustering clearly distinguished chemosensitive and chemoresistant tumors from the 25 serous EOC samples (training set), and consecutive class prediction analysis was used to develop a 43-gene classifier that was further validated in an independent cohort of 15 serous EOC patients and 2 patients with other ovarian cancer histotypes (test set). The 43-gene predictor set properly classified serous EOC patients at high risk for early ( $\leq 22$ months) versus late ( $>22$ months) relapse
\end{abstract}

Correspondence to: Dr Dimcho Bachvarov, CHUQ-Cancer Research Centre, Hôpital Hôtel-Dieu de Québec, 9 rue McMahon, Québec G1R 2J6, Canada

E-mail: dimtcho.batchvarov@crhdq.ulaval.ca

Key words: serous epithelial ovarian cancer, response to chemotherapy, gene expression, DNA microarray, gene predictor set after initial CT. Thus, gene expression array technology can effectively classify serous EOC tumors according to CT response. The proposed 43 -gene model needs further validation.

\section{Introduction}

Ovarian cancer is responsible for more cancer deaths among women in the Western world than all other gynecologic malignancies (1). If not detected early, this disease has a 5 -year survival rate of $<20 \%$. Epithelial carcinoma of the ovary is characterized by presentation at an advanced stage, spreads primarily by an intraperitoneal route, and relative sensitivity to CT. An initial surgical approach is essential for aggressive cytoreduction and proper staging of the disease process, which in turn improves response to $\mathrm{CT}$ and survival (2). CT has had an increasingly important role in the effective treatment of ovarian cancer. Combination CT with paclitaxel (taxol) plus a platinum compound (carboplatin or cisplatin) is the current regimen of choice for the treatment of advanced EOC (3). A number of clinical issues, however, are unresolved including drug dosage and schedule, duration of treatment, and route of administration (4). Indeed, although significant proportions of women respond to CT, the majority of responders $(\sim 60-75 \%)$ eventually relapse and die from recurrent disease (5-8). CT resistance in ovarian cancer is broad and encompasses diverse, unrelated drugs, suggesting more than one mechanism of resistance. A number of cellular factors have displayed increased expression and activity in drug-resistant ovarian cancer lines and/or tumor tissues (9-18), but consecutive in vivo studies have failed to assess their clinical importance and to translate them into recommendations for specific therapies or prognosis in ovarian cancer patients (19-21).

To avoid unnecessarily subjecting a patient to the side effects of anticancer drugs, it is a matter of urgency to understand the molecular mechanisms of drug resistance and to establish a diagnostic method to determine sensitivity to CT in patients with advanced ovarian cancer. Recent advances in expression genomics through global transcript analysis have led to the molecular classification of cancers (22-25) and the prediction of outcome and treatment response (26-29). 
In the present study, gene expression patterns were analyzed in primary tumor samples obtained upon surgery from patients with advanced serous EOC in an attempt to identify specific molecular signatures of serous EOC tumors according to their response to initial CT. The initial group comprised 15 resistant tumors from patients with progressive disease under CT or displaying recurrence in the first 6 months, and 10 sensitive tumors from patients with a TTR of at least 30 months. These conservative clinical criteria for defining first-line platinum sensitivity and resistance were employed to exclude tumors with intermediate levels of resistance. The serous EOC histotype was chosen because serous adenocarcinomas represent the most frequent type $(\sim 80 \%)$ of EOC $(30,31)$. Moreover, we wanted to use a more homogeneous set of tumor samples for our gene expression analyses, since different ovarian cancer histotypes display distinct expression patterns (32). First, the expression profiles of all 25 serous EOC tumors were independently analyzed which allowed the identification of specific sets of differentially expressed genes that might be functionally implicated in the evolution of the chemoresistant or the chemosensitive phenotype. Next, by performing gene expression comparison of the 25 primary chemosensitive and chemoresistant serous EOC tumors we were able to clearly distinguish chemosensitive and chemoresistant tumors from the 25 serous EOC samples by hierarchical clustering, and to consecutively identify a 43-gene classifier that was further tested in an independent cohort comprising 15 serous EOC tumors, one clear cell carcinoma and one endometrioid carcinoma. Our results provide the basis for extended study to further refine our predictor gene set which could help to overcome drug resistance and ameliorate ovarian cancer treatment.

\section{Materials and methods}

Patients and tissue specimens. Primary cancer tissues were obtained for expression profiling analysis prior to initial CT from 40 patients with invasive serous papillary adenocarcinoma of the ovary (FIGO stage IIIC and IV, grade 2 and 3) at the Hotel-Dieu de Quebec Hospital, Quebec, Canada. The patients received CT following debulking surgery between 1998 and 2003. All tumors were histologically classified according to the criteria defined by the World Health Organization. The CT treatment was completed for all patients and the response to treatment was evaluated following the RECIST group guidelines (33). Time to recurrence (TTR) was added as a supplementary variable, defined as the time interval between the last cycle of the initial CT regimen and recurrence.

The 25 serous EOC patients initially included in the study were formally divided into two groups based on response to CT. The sensitive group (1S-10S) showed a TTR of at least 30 months, while in the resistant group the disease progressed under CT or during the first 6 months following CT (TTR $\leq 6$ months) (Table IA). These 25 patients were further used for predictor marker discovery (training set), and an additional 15 serous EOC patients were analyzed as an independent validation set (test set). Two patients with different histological subtypes of ovarian cancer (one patient with clear cell carcinoma and one patient with endometrioid carcinoma) were also included in the test set (Table IB).
Tumor tissue from all patients was snap-frozen in liquid nitrogen within $1 \mathrm{~h}$ after surgery. A control section was cut from the bloc and stained with $\mathrm{H} \& \mathrm{E}$, in order to assess the percentage of tumor tissue; only samples with $>70 \%$ of tumor cells were selected. The study was approved by the Clinical Research Ethics Committee of the Hotel-Dieu de Quebec Hospital and all patients gave informed consent for voluntary participation.

Gene expression analysis. Gene expression analysis was carried out as previously described (34). Briefly, fluorescently labeled cRNA targets were generated from $0.5 \mu \mathrm{g}$ of total RNA in each reaction using a fluorescent linear amplification kit (Agilent) and 10.0 mM Cyanine 3- or 5-labeled CTP (PerkinElmer, Boston, MA), following the user's manual. Labeled cRNAs were purified using the RNeasy mini kit (Qiagen) and applied to the Human 1A (v2) oligonucleotide microarray (Agilent), containing 20,174 genes. One microgram of cyaninelabeled cRNA from one ovarian tumor was mixed with the same amount of reverse-color cyanine-labeled cRNA from a pool, which contained equal amounts of each RNA from the 25 serous EOC patients included in the training set. Array hybridization, washing, scanning and data extraction were performed as previously described (34). GeneSpring software (Agilent) was used to generate lists of selected genes and for different statistical and visualization methods, as described previously (34). Additionally, class prediction analysis was performed to predict the value, or 'class', of an individual parameter in an uncharacteristic sample or set of samples. Classification was generated by the 'Support Vector Machines' algorithm of GeneSpring using the training set and the test set for the parameter 'Response to initial CT'. Fisher's exact test method was used to select the predictor set of genes.

Semi-quantitative RT-PCR (sqRT-PCR). Validation of microarray data was performed for selected differentially expressed genes by sqRT-PCR as previously described (34). Upon analysis of the microarray data, we found that the tumor-differentially expressed 1 (TDE1) gene displayed no change in expression levels in all tumor samples analyzed and was used as an internal standard. Primers were designed for these loci with the sequences freely available from the Entrez Nucleotide database and the Primer3 algorithm for primer design (http://www-genome.wi.mit.edu/cgi-bin/primer/ primer3_www.cgi).

\section{Results}

Gene expression signatures of primary chemoresistant and chemosensitive tumors. The clinicopathological characteristics of the patients included in this investigation are presented in Table I. In our initial study, we included tumors from 25 serous EOC patients (comprising our training set; Table IA); the tumors were either grade 2 or 3 , stage IIIC and IV according to FIGO (International Federation of Obstetrics and Gynecology). All 25 patients had maximal debulking surgery, with residual disease of no more than $2 \mathrm{~cm}$. In the good responders (chemosensitive) group (1S to $10 \mathrm{~S}$ ), 3 patients had a minor histology component of endometrioid, clear cell and squamous histotype respectively. In this group were 
Table I. Patients' characteristics and class prediction data.

A, Clinicopathologic characteristics and class prediction analysis of the ovarian cancer patients from the training set

\begin{tabular}{|c|c|c|c|c|c|c|c|c|}
\hline \multicolumn{9}{|c|}{ Chemosensitive to initial treatment patients } \\
\hline No. & Patient code & Age & TTR (months) & Histological type & Stage & Grade & Adjuvant CT & Prediction $^{\mathrm{a}}$ \\
\hline $1 \mathrm{~S}$ & O-158 & 64 & $\geq 60$ & sEOC & IV & 2 & Carbo-Txl & S \\
\hline $2 \mathrm{~S}$ & O-165 & 66 & $\geq 60$ & $\mathrm{sEOC}+\mathrm{EC}$ & IIIC & 2 & Carbo-Txl & S \\
\hline $3 \mathrm{~S}$ & O-169 & 68 & $\geq 60$ & sEOC & IIIC & 3 & Carbo-Txl & $\mathrm{S}$ \\
\hline $4 \mathrm{~S}$ & O-217 & 55 & 45 & sEOC & IV & 2 & Cis-Txl & S \\
\hline $5 \mathrm{~S}$ & O-269 & 72 & $\geq 39$ & sEOC & IIIC & 3 & Carbo-Txl & S \\
\hline $6 \mathrm{~S}$ & O-301 & 56 & $\geq 36$ & sEOC & IIIC & 3 & Carbo-Txl & S \\
\hline $7 \mathrm{~S}$ & O-315 & 55 & $\geq 31$ & sEOC & IIIC & 3 & Carbo-Txl & S \\
\hline $8 \mathrm{~S}$ & O-324 & 54 & $\geq 32$ & sEOC & IIIC & 3 & Carbo-Txl & $\mathrm{S}$ \\
\hline $9 \mathrm{~S}$ & O-382 & 77 & 30 & $\mathrm{sEOC}+\mathrm{SCC}$ & IIIC & 3 & Carbo-Txl & S \\
\hline $10 \mathrm{~S}$ & $\mathrm{O}-400$ & 53 & $\geq 31$ & $\mathrm{sEOC}+\mathrm{CCC}$ & IIIC & 2 & Carbo-Txl & $S$ \\
\hline
\end{tabular}

Chemoresistant to initial treatment patients

No. Patient code Age TTR (months) Histological type Stage Grade Adjuvant CT Prediction

\begin{tabular}{|c|c|c|c|c|c|c|c|c|}
\hline $1 \mathrm{R}$ & O-137 & 58 & 6 & sEOC & IIIC & 2 & Carbo-Txl & $\mathrm{R}$ \\
\hline $2 \mathrm{R}$ & O-259 & 52 & 4 & sEOC & IIIC & 2 & Carbo-Txl & $\mathrm{R}$ \\
\hline $3 R$ & O-462 & 51 & 3 & sEOC & IV & 3 & Carbo-Txl & $\mathrm{R}$ \\
\hline $4 \mathrm{R}$ & O-536 & 45 & 2 & sEOC & IIIC & 3 & Carbo-Txl & $\mathrm{R}$ \\
\hline $5 \mathrm{R}$ & O-542 & 67 & 4 & sEOC & IIIC & 2 & Carbo-Txl & $\mathrm{R}$ \\
\hline $6 \mathrm{R}$ & O-132 & 83 & 0 & sEOC & IIIC & 3 & Carbo-Cyclph & $\mathrm{R}$ \\
\hline $7 \mathrm{R}$ & O-154 & 79 & 0 & sEOC & IIIC & 2 & Carbo-Cyclph & $\mathrm{R}$ \\
\hline $8 \mathrm{R}$ & O-221 & 83 & 0 & sEOC & IIIC & 3 & Carbo-Cyclph & $\mathrm{R}$ \\
\hline $9 \mathrm{R}$ & O-226 & 68 & 0 & sEOC & IIIC & 3 & Carbo-Txl & $\mathrm{R}$ \\
\hline $10 \mathrm{R}$ & O-456 & 54 & 0 & sEOC & IIIC & 3 & Carbo-Cyclph & $\mathrm{R}$ \\
\hline $11 \mathrm{R}$ & O-255 & 74 & 0 & sEOC & IV & 3 & Carbo-Txl & $\mathrm{R}$ \\
\hline $12 \mathrm{R}$ & O-347 & 55 & 0 & sEOC & IIIC & 2 & Carbo-Txl & $\mathrm{R}$ \\
\hline $13 R$ & O-454 & 63 & 0 & sEOC & IIIC & 3 & Carbo-Txl & $\mathrm{R}$ \\
\hline $14 \mathrm{R}$ & O-543 & 64 & 0 & sEOC & IIIC & 3 & Carbo-Txl & $\mathrm{R}$ \\
\hline $15 \mathrm{R}$ & O-123 & 78 & 0 & sEOC & IIIC & 3 & Carbo-Cyclph & $\mathrm{R}$ \\
\hline
\end{tabular}

B, Clinicopathologic characteristics and class prediction analysis of the ovarian cancer patients from the test set

\begin{tabular}{|c|c|c|c|c|c|c|c|c|}
\hline No. & Patient code & Age & TTR (months) & Histological type & Stage & Grade & Adjuvant CT & Prediction \\
\hline $1 \mathrm{~A}$ & O-527 & 72 & 0 & sEOC & IIIC & 2 & Carbo-Txl & $\mathrm{R}$ \\
\hline $2 \mathrm{~A}$ & O-489 & 86 & 2 & sEOC & IIIB & 3 & Carbo-Txl & $\mathrm{R}$ \\
\hline $3 \mathrm{~A}$ & O-487 & 67 & 3 & sEOC & IV & 2 & Carbo-Txl & $\mathrm{R}$ \\
\hline $4 \mathrm{~A}$ & O-332 & 68 & 4 & sEOC & IV & 3 & Carbo-Txl & $\mathrm{R}$ \\
\hline $5 \mathrm{~A}$ & O-130 & 70 & 8 & sEOC & IIIC & 2 & Carbo-Txl & $\mathrm{R}$ \\
\hline $6 \mathrm{~A}$ & O-337 & 53 & 10 & sEOC & IIIC & 3 & Carbo-Txl & $\mathrm{R}$ \\
\hline $7 \mathrm{~A}$ & O-73 & 69 & 14 & sEOC & IIIC & 3 & Carbo-Txl & $\mathrm{R}$ \\
\hline $8 \mathrm{~A}$ & O-358 & 62 & 15 & sEOC & IIIC & 3 & Carbo-Txl & $\mathrm{R}$ \\
\hline $9 \mathrm{~A}$ & O-122 & 58 & 18 & sEOC & IIIC & 3 & Carbo-Txl & $\mathrm{R}$ \\
\hline $10 \mathrm{~A}$ & O-320 & 68 & 20 & sEOC & IIIC & 2 & Carbo-Cyclph & $\mathrm{R}$ \\
\hline $11 \mathrm{~A}$ & $\mathrm{O}-44$ & 44 & 21 & sEOC & IV & 3 & Cis-Txl & $\mathrm{S}$ \\
\hline $12 \mathrm{~A}$ & O-150 & 46 & 21 & sEOC & IV & 3 & Cis-Txl & $\mathrm{R}$ \\
\hline $13 \mathrm{~A}$ & O-127 & 70 & 22 & sEOC & IIIC & 3 & Carbo-Txl & $\mathrm{R}$ \\
\hline $14 \mathrm{~A}$ & O-309 & 60 & $\geq 30$ & sEOC & IIIC & 3 & Carbo-Txl & $\mathrm{S}$ \\
\hline $15 \mathrm{~A}$ & O-104 & 66 & $\geq 50$ & sEOC & IIIC & 2 & Cis-Txl & $\mathrm{S}$ \\
\hline $16 \mathrm{~A}$ & O-503 & 56 & 0 & $\mathrm{CCC}$ & IIIC & $X$ & Carbo-Txl & $\mathrm{R}$ \\
\hline $17 \mathrm{~A}$ & O-411 & 54 & 12 & $\mathrm{EC}$ & IIA & 3 & Carbo-Txl & $\mathrm{R}$ \\
\hline
\end{tabular}

sEOC, serous epithelial ovarian cancer; CCC, clear cell carcinoma; SCC, squamous cell carcinoma; EC, endometrioid carcinoma; Cis, cisplatin; Carbo, carboplatin; Txl, taxol; Cyclph, cyclophosphamide; CT, chemotherapy; TTR, time to recurrence. ${ }^{\text {aClass }}$ prediction values are indicated for each patient following cross-validation of the training set and consecutive analysis of the test set using our 43-gene predictor model: S, chemosensitive; R, chemoresistant. 
Table II. List of selected differentially expressed genes (2-fold; $\mathrm{p}=0.001)$ in chemoresistant or chemosensitive serous EOC tumors. A, Selected down-regulated genes in chemoresistant serous EOC tumors

Gene symbol Function

CDCA1, FGF18, TOPK, PPIA, FGFR3, MAD2L1, EDN3, REG1B, MIA, AKR1C3, TM4SF8, HEC, CXCL10, CKS1B, ANLN, NPM1

Cell proliferation and cell cycle control

LAMA3), LAMB3, LAMC2, PCDHB2 PCDHB5, CDH16, CDH 19, REG1B

Cell adhesion

SLC3A1, SLC35F3, KCNJ16, S100A2, SLC2A1, CACNA2D3, SLC26A9,

Membrane transport

FOLR1, SLC9A9, SLC25A4

HPGD, LRIG1, NME1, NME2

Tumor (including ovarian tumor) suppression

UNG2, RFC5

DNA repair

FGFR3, PDCD5, TGM1

Apoptosis

SCGB2A1, SCGB2A2, SCGB1D1, HSPA4

Antagonists of the neoplastic phenotype

TNNI3

Angiogenesis inhibitor

AMY2B, CTSL2, TACSTD1, VIL1

Tumor marker

MMP1, TFPI2 (inhibitor of cell invasiveness)

Cancer invasion

B, Selected up-regulated genes in chemoresistant serous EOC tumors

Gene symbol

Function

ECGF1, APO E, IGF2R, CCL2, ARHGAP18, RHPN1, HDAC7A, laminin $\alpha 5$

Ovarian malignancy and tumor progression

NECL1, MAP3K11

Cell migration and invasion

LITAF, STAB1, CCL2

Inflammation

ABCA7, GCLC

Chemoresistance

$\mathrm{C}$, Selected down-regulated genes in chemosensitive serous EOC tumors

\begin{tabular}{ll}
\hline Gene symbol & Function \\
\hline HOXB13, CXCL2, CCK, FGFRL1, MMP19, VIP, gastrin, ITGBL1, & Tumor invasion and progression \\
MAGE-C1, MLC1, TKTL1, SELE, PPP2R1A, IL-6, IDAX, ACE, CNR1, & \\
STX11, ARRB1, MMEL2, AREG & \\
Hgß, Hg $\gamma$-G, SAA1, SAA2, CD36, ITGBL1, PLAT, KLK10, S100A1, & Ovarian and other tumor markers \\
HPSE2, ATF3, HYAL1, LOC63928, DIS3, DPEP1 & \\
FABP4, LPL, CD36, PAFAH2, APO C-I, APO L-4, ADN, SLC27A1 & Lipid metabolism and transport \\
SAA1, CXCL2, IL1F8, MASP2, CRLF2 & Inflammation \\
MYCN, NPM2, RAS-D2, RAD9A & Oncogenes
\end{tabular}

10 patients with a TTR interval of $\geq 30$ months. The poor responders (chemoresistant) group (1R to $15 \mathrm{R}$ ) comprised 15 patients with progressive disease under CT (in this case we assigned a TTR value of 0 months) or in the first 6 months following CT. Twenty patients received 6 cycles of combined CT based on a platinum compound (cisplatin or carboplatin) and taxol, and 5 patients received a platinum compound and cyclophosphamide. The median age for the chemoresistant group was 62 (range, 45-83), and the median age for the chemosensitive group was 57 (range, 53-77).
A reference RNA pool was made by mixing equal amounts of total RNA from all 25 serous EOC samples from the training set and the gene expression pattern of each tumor sample was compared to the pooled sample. Two hybridizations were carried out for every tumor against the reference sample using a fluorescent dye reversal (dye-swap) technique.

First, we separately evaluated the gene expression profiles of the chemoresistant and the chemosensitive serous EOC tumors in search for specific markers and/or molecular mechanisms that could determine the chemoresistant or the 


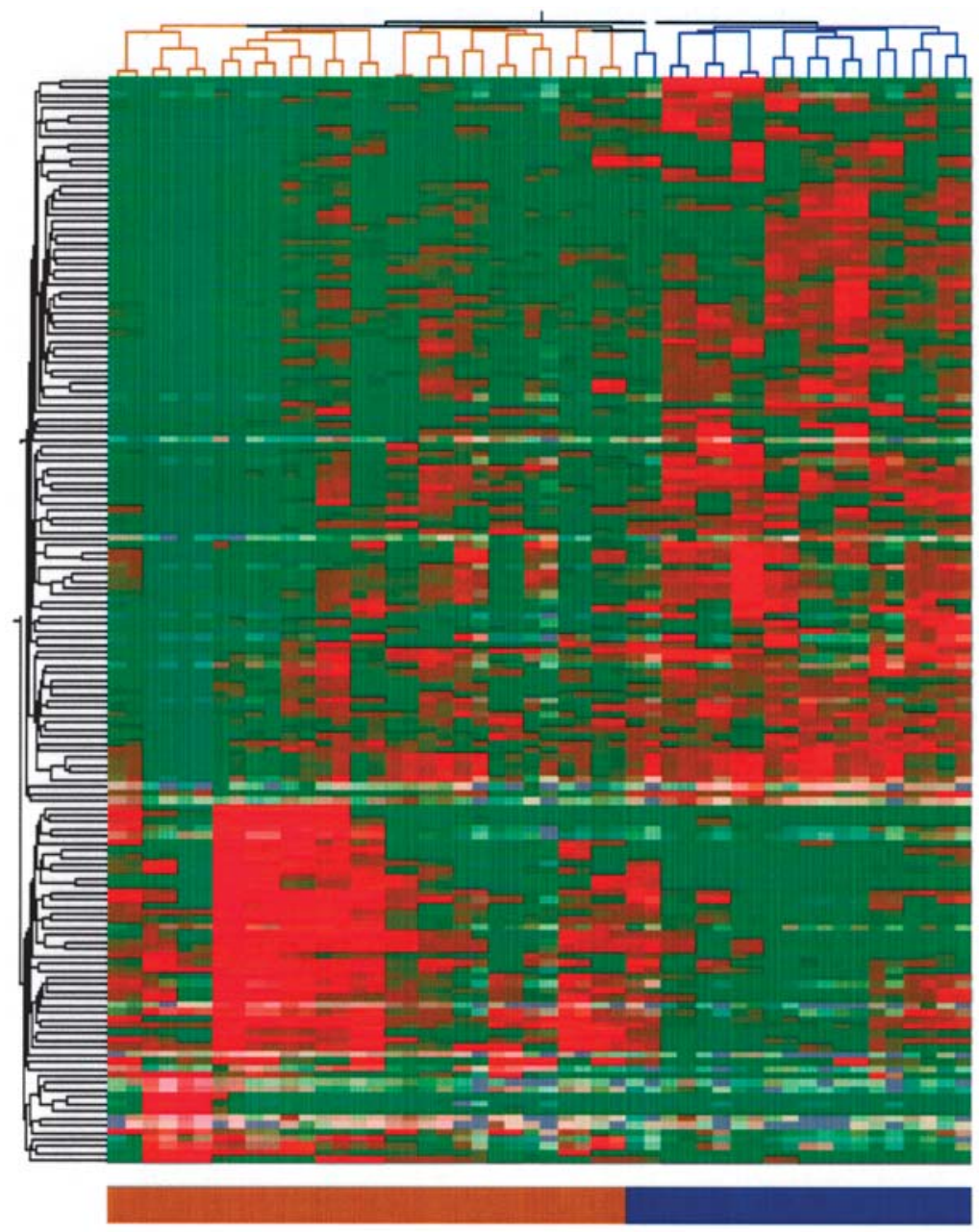

RESISTANT

SENSITIVE

Figure 1. Hierarchical clustering of 25 tumors in duplicate included in the training set based on the 155-genes list (p-value cutoff of 0.01 ) that discriminates serous EOC tumors according to their response to CT. The mean appears grey, whereas red signifies up-regulation, and green signifies down-regulation (see legend bar). Sensitive tumors are indicated in blue; resistant tumors are indicated in brown.

chemosensitive phenotype. For each of the two groups, a subset of differentially expressed genes was selected by initial filtering on confidence at $\mathrm{p}=0.001$, followed by filtering on expression level ( $\geq 2$-fold). Using these stringent selection criteria, we found 230 genes to be down-regulated and 60 genes to be up-regulated specifically in the chemoresistant group, while 163 genes were down-regulated and 20 genes were up-regulated specifically in the chemosensitive group. Notably, those down-regulated in the chemoresistant serous EOC tumors included a substantial number of genes implicated in cellular proliferation and cell cycle control, cell adhesion, membrane transport, as well as some genes involved in tumor (including ovarian tumor) suppression, DNA repair, apoptosis, and representing antagonists of the neoplastic phenotype (Table IIA). Several markers, known to be associated with ovarian malignancy and tumor progression, as well as genes implicated in cell migration and invasion, inflammation and chemoresistance were overexpressed in the chemoresistant samples (Table IIB). Down-regulated genes in the chemosensitive serous EOC tumors included numerous genes known to enhance tumor (including ovarian tumor) progression and invasion, ovarian and other tumor markers, genes involved in lipid metabolism and transport, inflammation, as well as several oncogenes (Table IIC).

Gene expression differences between primary chemoresistant and chemosensitive tumors. Next, we evaluated whether intrinsically chemoresistant and chemosensitive serous EOC tumors could be distinguished based on their gene expression profiles. We compared the expression data in all 25 tumors from the training set in search of discriminatory genes. First, we selected a subset of candidate genes by filtering on signal intensity (2-fold) to eliminate genes with uniformly low expression or genes whose expression did not vary significantly across the samples, retaining 377 genes. One-way ANOVA parametric test (Welch's t-test; variances not assumed equal) 
Table III. Predictor set of 43 genes differentially expressed between ovarian cancer patients who displayed sensitivity (TTR $>22$ months) or resistance (TTR $\leq 22$ months) to first-line chemotherapy.

\begin{tabular}{|c|c|c|}
\hline $\begin{array}{l}\text { Prognostic } \\
\text { strength }^{\mathrm{a}}\end{array}$ & $\begin{array}{l}\text { Gene } \\
\text { symbol }\end{array}$ & Gene name \\
\hline 18.79 & MPZL1 & Myelin protein zero-like 1 \\
\hline 18.27 & TOPK & T-LAK cell-originated protein kinase \\
\hline 17.79 & LSM7 & $\begin{array}{l}\text { LSM7 homolog, U6 small nuclear } \\
\text { RNA }\end{array}$ \\
\hline 17.79 & WDR12 & WD repeat domain 12 \\
\hline 17.00 & PTGDS & Prostaglandin D2 synthase \\
\hline 17.00 & PSMD14 & $\begin{array}{l}\text { Proteasome } 26 \mathrm{~S} \text { subunit, non- } \\
\text { ATPase, } 14\end{array}$ \\
\hline 16.53 & SNRPC & Small nuclear ribonucleoprotein $\mathrm{C}$ \\
\hline 16.53 & LDHB & Lactate dehydrogenase B \\
\hline 16.53 & NOP5/58 & Nucleolar protein NOP5/NOP58 \\
\hline 16.17 & LRRC59 & Leucine rich repeat containing 59 \\
\hline 16.12 & & Cyclophilin-related pseudogene \\
\hline 16.12 & MRPS24 & Mitochondrial ribosomal protein S24 \\
\hline 15.95 & HCAP-G & Chromosome condensation protein $\mathrm{G}$ \\
\hline 15.36 & PSMD1 & $\begin{array}{l}\text { Proteasome } 26 \mathrm{~S} \text { subunit, non- } \\
\text { ATPase, } 1\end{array}$ \\
\hline 15.34 & RSRC1 & Arginine/serine-rich coiled-coil 1 \\
\hline 15.34 & ZNF155 & Zinc finger protein 155 (pHZ-96) \\
\hline 15.34 & CAP2 & Adenylate cyclase-assoc. protein, 2 \\
\hline 15.18 & BOLA3 & BolA-like 3 (E. coli) \\
\hline 15.18 & DAP13 & $\begin{array}{l}13 \mathrm{kDa} \text { differentiation-associated } \\
\text { protein }\end{array}$ \\
\hline 15.18 & RBBP7 & Retinoblastoma binding protein 7 \\
\hline
\end{tabular}

14.89 C6orf129 Chromosome 6 ORF 129

$14.89 \quad$ NDUFB4 NADH dehydrogenase 1 B4

p53-inducible cell-survival factor

C12orf11

Chromosome 12 ORF 11

Cell division cycle associated 2

Signal transduction

Functions $^{\mathrm{b}}$

Elevated

levels in

Kinase activity; increased expression in highly Sensitive malignant cells (37)

mRNA processing

Sensitive

Cell proliferation

Sensitive

Inflammation; role in ovarian cancer progression (38)

Protease activity; confers chemoresistance to tumor cells (39)

mRNA splicing

Ovarian tumor marker (40)

Chaperone activity

Cell organization and cytoskeleton

Unknown function

Protein synthesis

Cell cycle control

Protease activity; role in apoptosis of leukemia cells (41)

Unknown function

Transcription

Adenylate cyclase activation

Cell proliferation and cell cycle regulation

Cell differentiation

Resistant

Sensitive

Sensitive

Sensitive

Sensitive

Sensitive

Sensitive

Sensitive

Sensitive

Sensitive

Sensitive

Sensitive

Sensitive

Sensitive

Sensitive

Cell proliferation; important role in physiology and pathology of ovarian tissue (42)

Unknown function

Electron transport; different NADH dehydrenase subunits are implicated in tumor progression (43-45) and response to treatment $(46,47)$

Apoptosis

Unknown function

Cell cycle regulation

Unknown function

Apoptosis; potentiator of cisplatin-based

chemotherapy (48)

Protein synthesis

Unknown function

Aminopeptidase (hydrolase) activity

Electron transport

Protein synthesis

Lipid metabolism; altered expression

linked to carcinogenesis (49)

Radioresistance of cancer cells (50)
Sensitive

Sensitive

Sensitive

Sensitive

Sensitive

Sensitive

Sensitive

Sensitive

Sensitive

Sensitive

Resistant

Sensitive

Sensitive

Resistant

Sensitive 
Table III. Continued.

\begin{tabular}{|c|c|c|c|c|}
\hline $\begin{array}{l}\text { Prognostic } \\
\text { strength }^{\mathrm{a}}\end{array}$ & $\begin{array}{l}\text { Gene } \\
\text { symbol }\end{array}$ & Gene name & Functions $^{\mathrm{b}}$ & $\begin{array}{l}\text { Elevated } \\
\text { levels in }\end{array}$ \\
\hline 13.86 & ALDH9A1 & $\begin{array}{l}\text { Aldehyde dehydrogenase } 9, \text { member } \\
\text { A1 }\end{array}$ & $\begin{array}{l}\text { Electron transport and oxidoreductase activity; } \\
\text { implicated in ovarian carcinogenesis and } \\
\text { chemoresistance ( } 51)\end{array}$ & Sensitive \\
\hline 13.78 & STC2 & Stanniocalcin 2 & $\begin{array}{l}\text { Signal transduction; associated with tumor } \\
\text { ER status in breast cancer cells ( } 52)\end{array}$ & Sensitive \\
\hline 13.78 & ACAT2 & Acetoacetyl Coenzyme A thiolase & $\begin{array}{l}\text { Lipid metabolism; biomarker for hepato- } \\
\text { cellular carcinoma ( } 53 \text { ) }\end{array}$ & Sensitive \\
\hline 13.78 & ZNF180 & Zinc finger protein 180 (HHZ168) & Transcription & Sensitive \\
\hline 13.72 & GPR49 & G protein-coupled receptor 49 & $\begin{array}{l}\text { Signal transduction; involved in the } \\
\text { development of hepatocellular carcinomas (54) }\end{array}$ & Sensitive \\
\hline 13.72 & HSPA4 & Heat shock $70 \mathrm{kDa}$ protein 4 & $\begin{array}{l}\text { Stress response; confers resistance to apop- } \\
\text { tosis in ovarian cancer cells }(55)\end{array}$ & Sensitive \\
\hline 13.72 & DUSP2 & Dual specificity phosphatase 2 & Protein dephosphorylation & Resistant \\
\hline 13.23 & AD024 & AD024 protein & Mitosis & Sensitive \\
\hline 13.23 & BRRN1 & Barren homolog (Drosophila) & Chromosome condensation & Sensitive \\
\hline
\end{tabular}

aAs determined by the 'Support Vector Machines' algorithm of the GeneSpring class prediction analysis. ${ }^{\mathrm{b}}$ Some references indicate functions relevant to cancer biology and response to treatment.

was further used to select discriminatory genes. t-test with p-value cutoff of 0.01 selected 155 genes for which expression differed in primary sensitive and resistant tumors. Clustering analysis based on the 155-genes list was performed using the standard Condition Tree algorithm provided in GeneSpring and revealed the formation of two major cluster groups that perfectly correspond with response to initial CT treatment (Fig. 1). The 155-genes list is presented in Supplementary Table I.

The 155 genes differently expressed at p-value cutoff of 0.01 were up-regulated or down-regulated at least 2-fold in chemoresistant tumors in comparison with chemosensitive tumors. Functional classes of these differently expressed genes mainly include metabolism (30\%), cell growth and maintenance $(18 \%)$, signal transduction $(12 \%)$, immune response (12\%), cell organization and biogenesis $(11 \%)$, transport $(9 \%)$ and apoptosis $(3 \%)$; the remainder $(5 \%)$ have unknown functions.

Fifty-three genes from the 155-genes list were up-regulated in chemoresistant tumors. Major classifications of these genes include signal transduction, metabolism, cell growth and maintenance and immune response. Notably, $\sim 22 \%$ of all up-regulated genes in resistant tumors are associated with inflammatory and immune responses (including chemokine $\mathrm{C}-\mathrm{C}$ and $\mathrm{C}-\mathrm{X}-\mathrm{C}$ motif ligands, several serum amyloid A family members and prostaglandin D2 synthase). Genes downregulated in resistant tumors (102 genes) are mainly involved in metabolism, cell growth and maintenance, cell organization and biogenesis.

Cross-validation of the training set. Next, we cross-validated the 25 tumor samples of the training set in an attempt to identify the minimal list of genes that can correctly classify the tumor samples from this set as chemoresistant or chemosensitive. Classification was generated using the 'Support Vector Machines' algorithm of the class prediction analysis of GeneSpring. The 25 serous EOC tumor samples were cross-validated for the parameter 'Response to initial CT'. We began validation analysis using an expanded gene list of all 1.4-fold filtered $(2,514)$ genes to avoid selection bias $(35,36)$. Fisher's exact test method was used to select the minimal gene number with perfect class prediction score. Using this analysis we identified a 43-gene predictor gene set (Table III) that correctly classified all primary sensitive and resistant tumors included in the training set (Table IA).

Confirmation of the expression measurements. To confirm measurement of RNA concentrations, expression values derived from adjusted Agilent data were correlated with values from sqRT-PCR for 21 variably expressed genes (Table IV). Validation of differential gene expression was performed for selected genes from the 43-gene predictor set (ACAT2, ALDH9A1, PTGDS, LDHB, RBBP7, TOPK), as well as from a number of genes that were down-regulated (GSTA1, HSPE1, NDUFB3, SCGB2A1, CTSL2, ASNS, PRSS2, BMO39 SDHC) or up-regulated (ECGF1, APOE, CD36, FOSB) in the resistant serous EOC tumors, as well as 2 genes (HBB, SAA1) that were down-regulated in the sensitive serous EOC group. Mean expression values were positive for all 21 genes and significantly positive $(\mathrm{p} \leq 0.05)$ for 13 of 21 genes.

Validation in an independent cohort (test set). Consecutively, 15 serous EOC patients that exhibited more diverse TTR values ranging between 0 and $\geq 50$ months were used as a test set for the validation of the predictive limits of the 43-gene 
Table IV. Correlation of mRNA expression data from the training set with sqRT-PCR derived values.

\begin{tabular}{|c|c|c|c|c|}
\hline Gene name & GeneBank & Mean value chemoresistant ${ }^{\mathrm{a}}$ & Mean value chemosensitive & p-value \\
\hline ACAT2 & AF356877 & 1,30816668 & 1,30290174 & 0.8345 \\
\hline ALDH9A1 & NM_000696 & 0,94065391 & 1,45774098 & 0.0445 \\
\hline ASNS & ВC014621 & 1,90588828 & 0,67766433 & 0.0060 \\
\hline CD36 & M98398 & 3,56331854 & 0,5092241 & 0.0140 \\
\hline FOSB & NM_006732 & 0,33831546 & 0,10256704 & 0.4657 \\
\hline GSTA1 & S49975 & 0,17409568 & 0,37106005 & 0.0274 \\
\hline HSPE1 & ВС030260 & 0,2688147 & 0,73120117 & 0.6399 \\
\hline LDHB & ВC015122 & 1,31411078 & 1,18463644 & 0.1551 \\
\hline NDUFB3 & BC018183 & 1,36570113 & 3,08019435 & 0.0252 \\
\hline PTGDS & AK075333 & 0,71857437 & 0,56139953 & 0.0206 \\
\hline PRSS2 & ВC030260 & 0,57747991 & 0,47947217 & 0.1218 \\
\hline RBBP7 & NM_002893 & 1,11056746 & 1,99232818 & 0.1007 \\
\hline SDHC & NM_003001 & 0,84320883 & 1,972385 & 0.0031 \\
\hline TOPK & AB027249 & 0,47959928 & 0,95206733 & 0.0073 \\
\hline BM039 & NM_018455 & 0,26673712 & 0,49436265 & 0.0092 \\
\hline SCGB2A1 & AF071219 & 2,1962592 & 3,16022742 & 0.0361 \\
\hline CTSL2 & AB001928 & 1,29356079 & 2,20727353 & 0.1733 \\
\hline ECGF1 & M63193 & 1,47680917 & 0,55276644 & 0.0100 \\
\hline APOE & NM_000041 & 1,57108933 & 0,78477098 & 0.0072 \\
\hline HBB & ВC007075 & 2,86510402 & 1,06310064 & 0.0416 \\
\hline SAA1 & NM_000331 & 3,84237549 & 2,54028984 & 0.1886 \\
\hline
\end{tabular}

${ }^{a}$ Mean value was calculated as the mean expression value for given marker in all resistant or sensitive tumor samples of the training set.

classifier. Fourteen patients had serous EOC, stage IIIC or IV, grade 2 or 3 ; one patient had serous EOC stage IIIB grade 3 . The median age was 66 years (range 44-86). After debulking surgery, the patients received 6 cycles of CT with a platinum compound and taxol (14 cases) or a platinum compound and cyclophosphamide (1 case). In a preliminary attempt to validate our selected predictor gene list in other histotypes of ovarian cancer, we have also included in the test set one patient with clear cell carcinoma stage IIIC and one patient with endometrioid carcinoma stage IIA, grade 3 . The clinical characteristics of all 17 patients from the test set are shown in Table IB. The gene expression pattern of each tumor sample of the test set was compared to that of the pooled reference sample used for cross-validation of the training set. All serous EOC patients from the test set displaying TTR values of $\leq 22$ months were classified as resistant to first-line CT treatment with the exception of one serous EOC patient with TTR of 21 months that was classified as sensitive, while the serous EOC patients with TTR $\geq 30$ months were classified as sensitive. The two additional patients with different histological subtypes of ovarian cancer (TTR values of 0 and 12 months, respectively) were correctly classified as resistant with our 43-gene predictor set. All data from the validation analysis of the test set are presented in Table IB.

\section{Discussion}

In the present study, we initially analyzed the gene expression profiles in primary tumor samples of 10 serous EOC patients that displayed a good response to CT (TTR $\geq 30$ months) and 15 serous EOC patients with a poor response to CT (TTR $\leq 6$ months, aiming to discover specific factors or mechanisms that determine response to first-line treatment and/or disease progression. The majority of these patients were treated postoperatively with a platinum compound and taxol; five patients were treated with carboplatin and cyclophosphamide (Table IA). Our goal was to determine the profile of two definite groups of tumors with different responses to CT, and to identify those genes that best distinguish the two groups. For this reason, we chose to use a pool of equal amounts of total RNA from each tumor as reference RNA. This has two advantages: firstly, it maximizes differences among tumor samples; and secondly, it ensures accurate quantification of expression levels for genes that are not expressed or are expressed at very low levels in a universal reference sample (56). Moreover, a pooled reference design is preferable when the major goal of a microarray experiment represents clustering and class prediction analysis (57).

Serous EOC displayed distinctive gene expression according to their response to $\mathrm{CT}$. Thus, different genes implicated 
in tumor and neoplastic phenotype suppression, cell adhesion and apoptosis were down-regulated in the resistant tumor serous EOC samples (Table IIA). Interestingly, the expression of numerous genes representing positive regulators of cell proliferation was suppressed in the resistant serous EOC tumors (Table IIA), which supports the concept of ours and others that a decreased proliferation state may be involved in the development of acquired chemoresistance (34,58-62). Down-regulated genes in the resistant group also comprised different membrane transporters and channels including amino acid (SLC3A1), nucleoside (SLC25A4) and folate transporters (FOLR1), $\mathrm{Ca}^{2+}$ channels and binding proteins (CACNA2D3, S100A2), and different ion transporters and channels (KCNJ16, SLC26A9, SLC9A9). Multiple types of membrane transporters and channels play important roles in sensitivity and resistance to anticancer drugs (63). Thus similar to our findings, the suppression of the S100A2 gene was previously associated with chemoresistance (64). Moreover, it was demonstrated that solute carrier (SLC) transporters, such as folate, nucleoside, and amino acid transporters, commonly increase chemosensitivity by mediating the cellular uptake of hydrophilic drugs, and the expression of different sodium, chloride, potassium, and other ion channels correlated with drug sensitivity and activity (65). Hence, the suppressed expression of the above transporter genes may contribute to the chemoresistant serous EOC phenotype. On the contrary, one member (ABCA7) of the $\mathrm{ABC}$ transporter family known to confer drug resistance by enhancing drug efflux $(63,65)$, was up-regulated in the chemoresistant serous EOC tumors. Overexpressed genes in the resistant group also included various genes implicated in ovarian malignancy and tumor progression, cell migration/ invasion and inflammation (Table IIB). These data confirm our recent findings that genes functionally involved in mechanisms of chemoresistance and ovarian tumor progression are commonly upregulated in post-CT (chemoresistant) ovarian tumors (34).

The sensitive serous EOC phenotype was mainly characterized by the suppression of different genes known to be functionally involved in disease progression, including genes responsible for tumor invasion, inflammatory mediators, various tumor markers and some oncogenes (Table IIC). The observed down-regulation of several oncogenes (MYCN, NPM2, RAS-D2, RAD9A; Table IIC) may additionally support the sensitive phenotype since elevated transcription of some oncogenes including c-Myc and Ras has been previously linked to multidrug resistance (66-68). In sensitive tumors, we have also monitored the down-regulation of different genes involved in control of lipid metabolism and transport. Indeed, enhanced lipid and protein degradation is a common finding among cancer patients. Alterations in the serum lipolytic activity of cancer patients correlate with response to therapy as patients who showed a positive response to CT also showed a decrease in their plasma levels of lipolytic activity (69). Ovarian cancer patients exhibit altered lipid metabolism and the degree of these alterations has been previously linked with response to therapy, as these metabolic alterations may influence disease outcome (70). Our data suggest that lower lipid metabolism rates might improve treatment response in serous EOC patients.

As a further step in the analysis of our initial data (training) set, we first looked for gene expression patterns that could discriminate good from poor responders upon initial CT of serous EOC patients. Clustering analysis, based on a set of 155 discriminatory genes, accurately distinguished primary serous EOC tumors according to their response to CT (Fig. 1). Fifty-three of these genes were overexpressed in the treatment-resistant cluster with major categories including immune and inflammatory response, regulation of transcription and hemoglobin synthesis. These results are not unexpected since: a) different inflammatory mediators, which play diverse roles such as inducing angiogenesis, invasion, autocrine growth loops and resistance to apoptosis, are shown to be elevated in ovarian carcinoma (71); b) some of the overexpressed transcription regulators (FOSB, FOS, NR4A1, NR4A2 and NR4A3) are shown to be associated with cancer progression and invasion $(72,73)$; c) $\mathrm{Hb}-\alpha$ and $\mathrm{Hb}-\beta$ were recently characterized as ovarian cancer biomarker proteins (74). Of the 102 genes overexpressed in the good response group, major categories were signal transduction, metabolism, regulation of transcription and nucleosome assembly (almost all histone genes); cell cycle regulation, cell adhesion, cytoskeleton structure, transport and apoptosis. In sensitive tumors, genes involved in cell cycle control (e.g., overexpression of CDCA1, CDCA7, BIRC5, BUB1 and CKS2) and apoptosis (e.g., overexpression of Siva and PDCD5) seem to contribute to sensitivity to CT. Differences in RNA expression were confirmed by sqRT-PCR for a sample of genes.

Next, an additional statistical approach (class prediction analysis) was applied to specifically search for the minimal set of genes that could predict response to first-line CT. This led to the identification of a 43-gene predictive model that correctly classified all 25 tumors based on response to initial CT. Our predictor model was subsequently validated in an independent cohort of 15 serous EOC patients and 2 patients with other ovarian cancer histotypes. The 43-gene model classified most serous EOC tumors with TTR $\leq 22$ months as resistant to first-line $\mathrm{CT}$, with the exception of one serous EOC tumor with TTR of 21 months that was classified as sensitive. The serous EOC tumors with TTR $\geq 30$ months were classified as sensitive. Thus according to our predictive method, the 21- to 22-month TTR interval may represent the turning point for our 43-gene predictor in classifying women with advanced serous EOC destined for early (TTR $\leq 22$ months) or late (TTR $>22$ months) relapse following CT treatment. Indeed, this transition period coincides with the literature data for median progression-free survival (20-22 months) of ovarian cancer patients with optimally debulked advancedstage disease treated with platinum-paclitaxel $(75,76)$. Similarly, a 14-gene predictive model for treatment outcome in ovarian cancer was previously developed (75) that could discriminate women at high risk for early ( $\leq 21$ months) versus late ( $>21$ months) relapse after initial CT. Furthermore, the fact that one clear cell carcinoma patient and one endometrioid carcinoma patient (TTR values of 0 and 12 months respectively) were both correctly classified as resistant with our 43-gene model, as well as the presence in the training set of three patients with mixed histotypes, is indicative for the possible application of our predictor set in other ovarian cancer histotypes.

Our 43-gene classifier list does not include many genes that have been implicated in drug resistance based on studies 
in model systems but, rather, identifies expression patterns of genes that could be used as a predictive test for response to CT. In this regard, the present results additionally parallel those of Hartmann et al, who identified a gene expression profile in ovarian cancer patients that correlated with drug sensitivity and treatment outcome but also contained a paucity of transcripts commonly implicated in resistance (77). It is provocative to speculate on the biologic function of the 43 genes that form our current predictor. Indeed, many of these genes need not have a proximal role in the biologic function that they predict. They may be robust but distant downstream transcriptional effects of biologic events that influence drug sensitivity. Furthermore, informative gene lists can change substantially as the training set size from which they are generated increases. The rank order of genes is particularly susceptible to change from one list to another. Therefore, from the vantage point of gaining mechanistic insight into the biology of CT sensitivity or resistance, these results should be regarded as hypothesis-generating only. However, it was encouraging to see that different genes in our marker set of 43 have been shown previously to be involved in disease progression (TOPK, PTGDS, LDHB, RBBP7, NDUFB4, ACADVL, ALDH9A1, ACAT2, GPR49), apoptosis (PSMD1, Siva, P53CSV, HSPA4), or response to treatment (PSMD14, NDUFB4, CCT6A, ALDH9A1) in different cancer types including ovarian carcinoma (see Table III for details). It is interesting to note that some of the above listed and several other genes from our predictive gene list are involved in the regulation of cellular proliferation or cell cycle control (TOPK, PTGDS, WDR12, HCAP-G, BOLA3, RBBP7, CDCA2, ADO24, BRRN1) which supports once more the concept that the modulation of the cellular proliferative rate could be determinative for CT response (34,56-60).

Several recent studies have used gene expression profiling to predict disease prognosis and survival $(78,79)$ and response to CT $(62,77,80,81)$ in ovarian cancer patients. These studies have identified different prognostic and predictor gene sets which can distinguish early from late relapse or disease progression; however, no significant overlap was found between the individual predictor lists. Our 43-gene predictor set also does not display any evident similarity with the predictor sets identified so far. These differences could be due to several reasons including various criteria of patient selection and the utilization of different gene expression platforms (nylon cDNA arrays, Affymetrix chips, Agilent oligonucleotide microarrays). Additionally, our analysis was based mostly on primary serous EOC tumors, while the other groups have used mixed histotypes of ovarian tumors, including recurrent and metastatic tumors. Although all of these studies, including ours, suggest that gene expression profiling is capable of defining prognosis and response to treatment, additional validation is required to determine the ultimate value of this approach in clinical practice. Also, combining the different predictor gene sets, while posing challenging informatics problems, might be much more informative.

In conlusion, gene expression profiling could discriminate serous EOC tumors according to their response to CT. Our data suggest that the intrinsic chemoresistance in serous EOC cells may be attributed to the combined action of different molecular mechanisms and factors linked with drug influx and efflux and cell proliferation, as the possible implications of other molecular events, including altered metabolism, apoptosis and inflammation, cannot be excluded. We have additionally developed a 43-gene classifier model that predicts early or late relapse to first-line CT in patients with advanced ovarian serous adenocarcinomas. Our data lend support to the suggestion that gene expression array technology can effectively classify serous EOC tumors according to response or resistance. To ultimately define the molecular portrait of ovarian cancers sensitive or resistant to first-line CT, these results should be validated in a study with a large prospective cohort including patients with different histological types of ovarian cancer. Further patient recruitment and analysis will refine the predictor gene list for classifying tumors based on response to initial therapy. This type of molecular profiling could have important clinical implications in resolving chemoresistance and defining the optimum treatment for an individual patient, thus reducing the use of unproductive treatments, unnecessary toxicity, and overall cost.

\section{Acknowledgements}

This study was supported by grant from the Cancer Research Society (CRS) of Canada (The Strategic Research Program on Genomics and Proteomics of Metastasic Cancer) and by financial support from the Cancer Research Network of the 'Fonds de la Recherche en Santé du Québec', Québec, Canada.

\section{References}

1. Wingo PA, Tong T and Bolden S: Cancer statistics. CA Cancer J Clin 45: 8-30, 1995.

2. Ozols RF: Current status of CT for ovarian cancer. Semin Oncol 22: 61-66, 1995

3. Dunton CJ: New options for the treatment of advanced ovarian cancer. Semin Oncol 24: S5-2-S5-11, 1997.

4. Markman M: Current status and future directions of platinum/ paclitaxel-based CT of ovarian cancer. Semin Oncol 24: S11-24S11-27, 1997.

5. Bookman MA, McGuire WP III, Kilpatrick D, Keenan E, Hogan WM, Johnson SW, O'Dwyer P, Rowinsky E, Gallion HH and Ozols RF: Carboplatin and paclitaxel in ovarian carcinoma: a phase I study of the Gynecologic Oncology Group. J Clin Oncol 14: 1895-1902, 1996.

6. McGuire WP, Hoskins WJ, Brady MF, Kucera PR, Partridge EE, Look KY, Clarke-Pearson DL and Davidson M: Cyclophosphamide and cisplatin compared with paclitaxel and cisplatin in patients with stage III and stage IV ovarian cancer. N Engl J Med 334: 1-6, 1996.

7. Ozols RF: Optimum CT for ovarian cancer. Int J Gynecol Cancer 10: 33-37, 2000.

8. Du Bois A, Luck HJ, Pfisterer J, Schroeder W, Blohmer JU, Kimmig R, Moebus V and Quaas J: Second-line carboplatin and gemcitabine in platinum sensitive ovarian cancer - a dosefinding study by the Arbeitsgemeinschaft Gynakologische Onkologie (AGO) Ovarian Cancer Study Group. Ann Oncol 12: 1115-1120, 2001.

9. Kita T, Kikuchi Y, Hirata J and Nagata I: Prognosis of ovarian cancer today. Cancer J 11: 201-207, 1998.

10. Pegg AE and Byers TL: Repair of DNA containing O6-alkylguanine. FASEB J 6: 2302-2310, 1992.

11. Eastman A and Schulte N: Enhanced DNA repair as a mechanism of resistance to cis-diamminedichloroplatinum(II). Biochemistry 27: 4730-4734, 1998

12. Yao KS, Godwin AK, Johnson SW, Ozols RF, O'Dwyer PJ and Hamilton TC: Evidence for altered regulation of $\gamma$-glutamylcysteine synthetase gene expression among cisplatin-sensitive and cisplatin-resistant human ovarian cancer cell lines. Cancer Res 55: 4367-4374, 1995 . 
13. Vanderzee AGJ, Vanommen B, Meijer C, Hollema H, Vanbladeren PJ and Devries EGE: Glutathione-S-transferase activity and isoenzyme composition in benign ovarian tumours, untreated malignant ovarian tumours and malignant ovarian tumours after platinum/cyclophosphamide CT. Br J Cancer 66: 930-936, 1992.

14. Shridhar V, Bible KC, Staub J, Avula R, Lee YK, Kalli K, Huang H, Hartmann LC, Kaufmann SH and Smith DI: Loss of expression of a new member of the DNAJ protein family confers resistance to chemotherapeutic agents used in the treatment of ovarian cancer. Cancer Res 61: 4258-4265, 2001.

15. Hengstler JG, Lange J, Kett A, Dornhofer N, Meinert R, Arand M, Knapstein PG, Becker R, Oesch F and Tanner B: Contribution of c-erbB-2 and topoisomerase II $\alpha$ to chemoresistance in ovarian cancer. Cancer Res 59: 3206-3214, 1999.

16. Liu JR, Fletcher B, Page C, Hu C, Nunez G and Baker V: Bcl-xL is expressed in ovarian carcinoma and modulates CT-induced apoptosis. Gynecol Oncol 70: 398-403, 1998.

17. Sasaki H, Sheng Y, Kotsuji F and Tsang BK: Down-regulation of X-linked inhibitor of apoptosis protein induces apoptosis in chemoresistant human ovarian cancer cells. Cancer Res 60: 5659-5666, 2000.

18. Li J, Feng Q, Kim JM, Schneiderman D, Liston P, Li M, Vanderhyden B, Faught W, Fung MF, Senterman M, Korneluk RG and Tsang BK: Human ovarian cancer and cisplatin resistance: possible role of inhibitor of apoptosis proteins. Endocrinology 142: 370-380, 2001.

19. Germain I, Têtu B, Brisson J, Mondor M and Cherian G: Markers of chemoresistance in ovarian carcinomas; an immunohistochemical study of 86 cases. Int J Gynecol Pathol 15: 54-62, 1996.

20. Eltabbakh GH and Awtrey CS: Current treatment for ovarian cancer. Expert Opin Pharmacother 2: 109-124, 2001.

21. Goff BA, Paley PJ, Greer BE and Gown AM: Evaluation of chemoresistance markers in women with epithelial ovarian carcinoma. Gynecol Oncol 81: 18-24, 2001.

22. Schmidt U and Begley CG: Cancer diagnosis and microarrays. Int J Biochem Cell Biol 35: 119-124, 2003.

23. Liu ET: Classification of cancers by expression profiling. Curr Opin Genet Dev 13: 97-103, 2003.

24. Raetz EA and Moos PJ: Impact of microarray technology in clinical oncology. Cancer Invest 22: 312-320, 2004.

25. Cuperlovic-Culf M, Belacel N and Ouellette RJ: Determination of tumour marker genes from gene expression data. Drug Discov Today 10: 429-437, 2005.

26. Mariadason JM, Augenlicht LH and Arango D: Microarray analysis in the clinical management of cancer. Hematol Oncol Clin North Am 17: 377-387, 2003.

27. Wulfkuhle J, Espina V, Liotta L and Petricoin E: Genomic and proteomic technologies for individualisation and improvement of cancer treatment. Eur J Cancer 40: 2623-2632, 2004.

28. Alaoui-Jamali MA, Dupre I and Qiang H: Prediction of drug sensitivity and drug resistance in cancer by transcriptional and proteomic profiling. Drug Resist Update 7: 245-255, 2004.

29. Wang Y: Gene expression-driven diagnostics and pharmacogenomics in cancer. Curr Opin Mol Ther 7: 246-250, 2005.

30. Auersperg N, Wong AS, Choi KC, Kang SK and Leung PC: Ovarian surface epithelium: biology, endocrinology, and pathology. Endocr Rev 22: 255-288, 2001.

31. Jemal A, Murray T, Ward E, Samuels A, Tiwari RC, Ghafoor A, Feuer EJ and Thun MJ: Cancer statistics, 2005. CA Cancer J Clin 55: 10-30, 2005.

32. Marquez RT, Baggerly KA, Patterson AP, Liu J, Broaddus R, Frumovitz M, Atkinson EN, Smith DI, Hartmann L, Fishman D, Berchuck A, Whitaker R, Gershenson DM, Mills GB, Bast RC Jr and Lu KH: Patterns of gene expression in different histotypes of epithelial ovarian cancer correlate with those in normal fallopian tube, endometrium, and colon. Clin Cancer Res 11: 6116-6126, 2005 .

33. Therasse P, Arbuck SG, Eisenhauer EA, Wanders J, Kaplan RS, Rubinstein L, Verweij J, van Glabbeke M, van Oosterom AT, Christian MC and Gwyther SG: New guidelines to evaluate the response to treatment in solid tumors. J Natl Cancer Inst 92: 205-216, 2000.

34. L'Esperance S, Popa I, Bachvarova M, Plante M, Patten N, Wu L, Têtu B and Bachvarov D: Gene expression profiling of paired tumor samples obtained prior to and following adjuvant chemotherapy: molecular signatures of chemoresistant tumors. Int J Oncol 29: 5-24, 2006.
35. Ambroise C and McLachlan GJ: Selection bias in gene extraction on the basis of microarray gene-expression data. Proc Natl Acad Sci USA 99: 6562-6566, 2002.

36. Simon R, Radmacher MD, Dobbin K and McShane LM: Pitfalls in the use of DNA microarray data for diagnostic and prognostic classification. J Natl Cancer Inst 95: 14-18, 2003

37. Simons-Evelyn M, Bailey-Dell K, Toretsky JA, Ross DD, Fenton R, Kalvakolanu D and Rapoport AP: PBK/TOPK is a novel mitotic kinase which is upregulated in Burkitt's lymphoma and other highly proliferative malignant cells. Blood Cells Mol Dis 27: 825-829, 2001.

38. Su B, Guan M, Zhao R and Lu Y: Expression of prostaglandin D synthase in ovarian cancer. Clin Chem Lab Med 39: 1198-1203, 2001.

39. Spataro V, Toda T, Craig R, Seeger M, Dubiel W, Harris AL and Norbury C: Resistance to diverse drugs and ultraviolet light conferred by overexpression of a novel human $26 \mathrm{~S}$ proteasome subunit. J Biol Chem 272: 30470-30475, 1997.

40. Yuce K, Baykal C, Genc C, Al A and Ayhan A: Diagnostic and prognostic value of serum and peritoneal fluid lactate dehydrogenase in epithelial ovarian cancer. Eur J Gynaecol Oncol 22: 228-232, 2001

41. Wang H, Liu S, Lu X, Zhao X, Chen S and Li X: Gene expression profile changes in NB4 cells induced by realgar. Chin Med J 116: 1074-1077, 2003.

42. Burns KH, Owens GE, Ogbonna SC, Nilson JH and Matzuk MM: Expression profiling analyses of gonadotropin responses and tumor development in the absence of inhibins. Endocrinology 144: 4492-4507, 2003.

43. Cheng Q, Lau WM, Tay SK, Chew SH, Ho TH and Hui KM: Identification and characterization of genes involved in the carcinogenesis of human squamous cell cervical carcinoma. Int J Cancer 98: 419-426, 2002.

44. Tarantul VZ and Hunsmann G: Mitochondrial polypeptides of the oxidative phosphorylation pathway as potential new targets for anti-cancer therapy. Med Hypotheses 56: 386-387, 2001.

45. Perumal SS, Shanthi P and Sachdanandam P: Therapeutic effect of tamoxifen and energy-modulating vitamins on carbohydratemetabolizing enzymes in breast cancer. Cancer Chemother Pharmacol 56: 105-114, 2005.

46. Zhu NX, Zheng S, Xu RZ, Gao RL, Shen JP and Yu RX: Identification of multidrug resistance related genes in leukemia by suppression subtractive hybridization. Zhonghua Xue Ye Xue Za Zhi 24: 14-17, 2003.

47. Shen XY, Zacal N, Singh G and Rainbow AJ: Alterations in mitochondrial and apoptosis-regulating gene expression in photodynamic therapy-resistant variants of HT29 colon carcinoma cells. Photochem Photobiol 81: 306-313, 2005.

48. Chu F, Barkinge J, Hawkins S, Gudi R, Salgia R and Kanteti PV: Expression of Siva-1 protein or its putative amphipathic helical region enhances cisplatin-induced apoptosis in breast cancer cells: effect of elevated levels of BCL-2. Cancer Res 65: 5301-5309, 2005.

49. Yeh CS, Wang JY, Cheng TL, Juan CH, Wu CH and Lin SR: Fatty acid metabolism pathway play an important role in carcinogenesis of human colorectal cancers by MicroarrayBioinformatics analysis. Cancer Lett 233: 297-308, 2006.

50. Higo M, Uzawa K, Kouzu Y, Bukawa H, Nimura Y, Seki N and Tanzawa H: Identification of candidate radioresistant genes in human squamous cell carcinoma cells through gene expression analysis using DNA microarrays. Oncol Rep 14: 1293-1298, 2005.

51. Tanner B, Hengstler JG, Dietrich B, Henrich M, Steinberg P, Weikel W, Meinert R, Kaina B, Oesch F and Knapstein PG: Glutathione, glutathione S-transferase alpha and pi, and aldehyde dehydrogenase content in relationship to drug resistance in ovarian cancer. Gynecol Oncol 65: 54-62, 1997.

52. Bouras T, Southey MC, Chang AC, Reddel RR, Willhite D, Glynne R, Henderson MA, Armes JE and Venter DJ: Stanniocalcin 2 is an estrogen-responsive gene coexpressed with the estrogen receptor in human breast cancer. Cancer Res 62: 1289-1295, 2002.

53. Song BL, Wang CH, Yao XM, Yang L, Zhang WJ, Wang ZZ, Yang JB, Qi W, Yang XY, Inoue K, Lin ZX, Zhang HZ, Kodama T, Chang CC, Liu YK, Chang TY and Li BL: Human acyl-CoA: cholesterol acyltransferase 2 gene expression in intestinal Caco- 2 cells and in hepatocellular carcinoma. Biochem J 394: 617-626, 2006. 
54. Yamamoto Y, Sakamoto M, Fujii G, Tsuiji H, Kenetaka K, Asaka M and Hirohashi S: Overexpression of orphan G-proteincoupled receptor, Gpr49, in human hepatocellular carcinomas with beta-catenin mutations. Hepatology 37: 528-533, 2003.

55. Hu W, Wu W, Verschraegen CF, Chen L, Mao L, Yeung SC, Kudelka AP, Freedman RS and Kavanagh JJ: Proteomic identification of heat shock protein 70 as a candidate target for enhancing apoptosis induced by farnesyl transferase inhibitor. Proteomics 10: 1904-1911, 2003.

56. Cao QJ, Belbin T, Socci N, Balan R, Prystowsky MB, Childs G and Jones JG: Distinctive gene expression profiles by cDNA microarrays in endometrioid and serous carcinomas of the endometrium. Int J Gynecol Pathol 23: 321-329, 2004.

57. Dobbin K and Simon R: Comparison of microarray designs for class comparison and class discovery. Bioinformatics 18: 1438-1445, 2002.

58. Itamochi H, Kigawa J, Sugiyama T, Kikuchi Y, Suzuki M and Terakawa N: Low proliferation activity may be associated with chemoresistance in clear cell carcinoma of the ovary. Obstet Gynecol 100: 281-287, 2002.

59. Muller V, Stahmann N, Riethdorf S, Rau T, Zabel T, Goetz A, Janicke F and Pantel K: Circulating tumor cells in breast cancer: correlation to bone marrow micrometastases, heterogeneous response to systemic therapy and low proliferative activity. Clin Cancer Res 11: 3678-3685, 2005.

60. Linn SC, Pinedo HM, van Ark-Otte J, van der Valk P, Hoekman K, Honkoop AH, Vermorken JB and Giaccone G: Expression of drug resistance proteins in breast cancer, in relation to CT. Int J Cancer 71: 787-795, 1997.

61. Yang KP, Liang YF and Samaan NA: Intrinsic drug resistance in a human medullary thyroid carcinoma cell line: association with overexpression of mdrl gene and low proliferation fraction. Anticancer Res 11: 1065-1068, 1991.

62. Jazaeri AA, Awtrey CS, Chandramouli GV, Chuang YE, Khan J, Sotiriou C, Aprelikova O, Yee CJ, Zorn KK, Birrer MJ, Barrett JC and Boyd J: Gene expression profiles associated with response to $\mathrm{CT}$ in epithelial ovarian cancers clinical cancer. Clin Cancer Res 11: 6300-6310, 2005.

63. Huang Y, Anderle P, Bussey KJ, Barbacioru C, Shankavaram U, Dai Z, Reinhold WC, Papp A, Weinstein JN and Sadee W: Membrane transporters and channels: role of the transportome in cancer chemosensitivity and chemoresistance. Cancer Res 64: 4294-4301, 2004.

64. Schmidt WM, Kalipciyan M, Dornstauder E, Rizovski B, Steger GG, Sedivy R, Mueller MW and Mader RM: Dissecting progressive stages of 5-fluorouracil resistance in vitro using RNA expression profiling. Int J Cancer 112: 200-212, 2004.

65. Huang Y and Sadee W: Membrane transporters and channels in chemoresistance and -sensitivity of tumor cells. Cancer Lett 239: 336-349, 2006 (Epub 2005 Oct 5).

66. Chin K-V, Ueda K, Pastan I and Gottesman MM: Modulation of activity of the promoter of the human MDR1 gene by Ras and p53. Science 255: 459-562, 1992.

67. Volm M, Kastel M, Mattern J and Efferth T: Expression of resistance factors (P-glycoprotein, glutathione S-transferase-pi, and topoisomerase II) and their interrelationship to protooncogene products in renal cell carcinomas. Cancer 71: 3981-3987, 1993.

68. Sabbatini ARM, Basolo F, Valentini P, Mattii L, Calvo S, Fiore L, Ciardiello $\mathrm{F}$ and Petrini $\mathrm{M}$ : Induction of multidrug resistance (MDR) by transfection of MCF-10A cell line with c-Ha-ras and c-erbB-2 oncogenes. Int J Cancer 59: 208-211, 1994.
69. Beck SA, Groundwater P, Barton C and Tisdale MJ: Alterations in serum lipolytic activity of cancer patients with response to therapy. Br J Cancer 62: 822-825, 1990.

70. Gercel-Taylor C, Doering DL, Kraemer FB and Taylor DD: Aberrations in normal systemic lipid metabolism in ovarian cancer patients. Gynecol Oncol 60: 35-41, 1996.

71. Altinoz MA and Korkmaz R: NF-kappaB, macrophage migration inhibitory factor and cyclooxygenase-inhibitions as likely mechanisms behind the acetaminophen- and NSAIDprevention of the ovarian cancer. Neoplasma 51: 239-247, 2004.

72. Hennigan RF, Hawker KL and Ozanne BW: Fos-transformation activates genes associated with invasion. Oncogene 9: 3591-3600, 1994.

73. Wansa KD and Muscat GE: TRAP220 is modulated by the antineoplastic agent 6-Mercaptopurine, and mediates the activation of the NR4A subgroup of nuclear receptors. J Mol Endocrinol 34: 835-848, 2005 .

74. Woong-Shick A, Sung-Pil P, Su-Mi B, Joon-Mo L, Sung-Eun N, Gye-Hyun N, Young-Lae C, Ho-Sun C, Heung-Jae J, ChongKook K, Young-Wan K, Byoung-Don H and Hyun-Sun J: Identification of hemoglobin-alpha and -beta subunits as potential serum biomarkers for the diagnosis and prognosis of ovarian cancer. Cancer Sci 96: 197-201, 2005.

75. Ozols RF, Bundy BN, Greer BE, Fowler JM, Clarke-Pearson D, Burger RA, Mannel RS, De Geest K, Hartenbach EM and Baergen R: Phase III trial of carboplatin and paclitaxel compared with cisplatin and paclitaxel in patients with optimally resected stage III ovarian cancer: a Gynecologic Oncology Group study. J Clin Oncol 21: 3194-3200, 2003.

76. Markman M, Bundy BN, Alberts DS, Fowler JM, ClarkPearson DL, Carson LF, Wadler S and Sickel J: Phase III trial of standard-dose intravenous cisplatin plus paclitaxel versus moderately high-dose carboplatin followed by intravenous paclitaxel and intraperitoneal cisplatin in small-volume stage III ovarian carcinoma: an intergroup study of the Gynecologic Oncology Group, Southwestern Oncology Group, and Eastern Cooperative Oncology Group. J Clin Oncol 19: 1001-1007, 2001.

77. Hartmann LC, Lu KH, Linette GP, Cliby WA, Kalli KR, Gershenson D, Bast RC, Stec J, Iartchouk N, Smith DI, Ross JS, Hoersch S, Shridhar V, Lillie J, Kaufmann SH, Clark EA and Damokosh AI: Gene expression profiles predict early relapse in ovarian cancer after platinum-paclitaxel CT. Clin Cancer Res 11: 2149-2155, 2005.

78. Berchuck A, Iversen ES, Lancaster JM, Pittman J, Luo J, Lee P, Murphy S, Dressman HK, Febbo PG, West M, Nevins JR and Marks JR: Patterns of gene expression that characterize longterm survival in advanced stage serous ovarian cancers. Clin Cancer Res 11: 3686-3896, 2005.

79. Spentzos D, Levine DA, Kolia S, Otu H, Boyd J, Libermann TA and Cannistra SA: Unique gene expression profile based on pathologic response in epithelial ovarian cancer. J Clin Oncol 23: 7911-7918, 2005

80. Spentzos D, Levine DA, Ramoni MF, Joseph M, Gu X, Boyd J, Libermann TA and Cannistra SA: Gene expression signature with independent prognostic significance in epithelial ovarian cancer. J Clin Oncol 22: 4700-4710, 2004.

81. Helleman J, Jansen MP, Span PN, van Staveren IL, Massuger LF, Meijer-van Gelder ME, Sweep FC, Ewing PC, van der Burg ME, Stoter G, Nooter K and Berns EM: Molecular profiling of platinum resistant ovarian cancer. Int J Cancer 118: 1963-1971, 2006.

Supplementary Table I. List of 155 genes used for cluster analysis.

\begin{tabular}{llll}
\hline P-value & Common & Genbank & \\
\hline 0.00922 & & & Rescription \\
0.00914 & CTSL2 & AB001928 & Cathepsin L2 \\
0.00904 & ATF3 & BC006322 & Activating transcription factor 3 \\
0.00904 & CDT1 & NM_030928 & DNA replication factor \\
0.0085 & PCDHB2 & AK027526 & Protocadherin B 2 \\
0.00845 & DPEP1 & J05257 & Dipeptidase 1 (renal)
\end{tabular}


Supplementary Table I. Continued.

\begin{tabular}{|c|c|c|c|}
\hline P-value & Common & Genbank & Description \\
\hline 0.00776 & VAMP4 & NM_003762 & Vesicle-associated membrane protein 4 \\
\hline 0.00769 & GEM & U10550 & GTP binding protein overexpressed in skeletal muscle \\
\hline 0.00683 & MGC13024 & NM_152288 & Hypothetical protein MGC13024 \\
\hline 0.00683 & ST6GalII & NM_032528 & $\beta$-galactoside $\alpha$-2,6-sialyltransferase II \\
\hline 0.00671 & SOX 2 & NM_003106 & SRY (sex determining region Y)-box 2 \\
\hline 0.0062 & KLF2 & AF134053 & Kruppel-like factor 2 (lung) \\
\hline 0.00615 & GABRE & U66661 & $\gamma$-aminobutyric acid (GABA) A receptor, epsilon \\
\hline 0.00585 & SCGB2A1 & AF071219 & Secretoglobin, family $2 \mathrm{~A}$, member 1 \\
\hline 0.00577 & HMGB2 & X62534 & High-mobility group box 2 \\
\hline 0.00564 & TLR8 & AF246971 & Toll-like receptor 8 \\
\hline 0.00555 & CXCL2 & ВC015753 & Chemokine (C-X-C motif) ligand 2 \\
\hline 0.00551 & CD36 & M98398 & CD36 antigen \\
\hline 0.00548 & & NM_152535 & Protein of unknown function [133-aa form] \\
\hline 0.00503 & KIAA1084 & NM_014910 & KIAA1084 protein \\
\hline 0.00484 & ATP5G3 & U09813 & ATP synthase, $\mathrm{H}^{+}$transporting, subunit $\mathrm{c}$, isoform 3 \\
\hline 0.00484 & CXCL12 & NM_000609 & Chemokine (C-X-C motif) ligand 12 \\
\hline 0.00484 & FOS & ВС004490 & v-fos FBJ murine osteosarcoma viral oncogene \\
\hline 0.00478 & FLJ39553 & NM_173549 & Hypothetical protein FLJ39553 \\
\hline 0.00477 & SCGB1D2 & AJ 224172 & Secretoglobin, family 1D, member 2 \\
\hline 0.00456 & PDCD5 & ВC015519 & Programmed cell death 5 \\
\hline 0.00445 & PRG1 & ВС015516 & Proteoglycan 1 , secretory granule \\
\hline 0.00429 & HBG2 & NM_000184 & Hemoglobin, $\gamma \mathrm{G}$ \\
\hline 0.00426 & LAMC2 & X73902 & Laminin, $\gamma 2$ \\
\hline 0.00419 & & & Protein of unknown function \\
\hline 0.00416 & MAGEF1 & ВC010056 & Melanoma antigen, family F, 1 \\
\hline 0.00415 & MGC12538 & NM_032746 & Hypothetical protein MGC12538 \\
\hline 0.00415 & PRSS16 & AF052514 & Protease, serine, 16 (thymus) \\
\hline 0.0038 & MGC1842 & ВC002924 & Hypothetical protein MGC1842 \\
\hline 0.0036 & PSPH & Y10275 & Phosphoserine phosphatase \\
\hline 0.00347 & KCP3 & NM_173853 & Keratinocytes associated protein 3 \\
\hline 0.00341 & RARRES1 & $\mathrm{U} 27185$ & Retinoic acid receptor responder (tazarotene induced) 1 \\
\hline 0.00338 & AMELY & M86933 & Amelogenin, Y-linked \\
\hline 0.00328 & UBL5 & AF313915 & Ubiquitin-like 5 \\
\hline 0.00318 & Z39IG & AJ132502 & Ig superfamily protein \\
\hline 0.00302 & PCDHB5 & ВC001186 & Protocadherin $\beta 5$ \\
\hline 0.0028 & DKFZP434B195 & AK075560 & Hypothetical protein DKFZp434B195 \\
\hline 0.0028 & SCGB2A1 & NM_002407 & Secretoglobin, family $2 \mathrm{~A}$, member 1 \\
\hline 0.00277 & GSTA1 & S49975 & Glutathione S-transferase A1 \\
\hline 0.00272 & FLJ35773 & NM_152599 & Hypothetical protein FLJ35773 \\
\hline 0.00253 & NNMT & ВC000234 & Nicotinamide N-methyltransferase \\
\hline 0.00252 & SAA1 & NM_000331 & Serum amyloid A1 \\
\hline 0.00233 & TYMS & ВС013919 & Thymidylate synthetase \\
\hline 0.00233 & UGT2B7 & ВC030974 & UDP glycosyltransferase 2, polypeptide B7 \\
\hline 0.00226 & KIAA1505 & AK056542 & KIAA1505 protein \\
\hline 0.00226 & SAA2 & NM_030754 & Serum amyloid A2 \\
\hline 0.00202 & FLJ30296 & NM_173495 & Hypothetical protein FLJ30296 \\
\hline 0.00195 & GPR27 & AB040799 & G protein-coupled receptor 27 \\
\hline 0.00192 & LAMA3 & L34155 & Laminin, $\alpha 3$ \\
\hline 0.00188 & NR4A2 & ВС009288 & Nuclear receptor subfamily 4 , group A, member 2 \\
\hline 0.00188 & TMEM14B & ВС013913 & Transmembrane protein 14B \\
\hline 0.0018 & MGC17330 & ВC011049 & HGFL gene \\
\hline 0.0018 & PAPLN & NM_173462 & Papilin, proteoglycan-like sulfated glycoprotein \\
\hline
\end{tabular}


Supplementary Table I. Continued.

\begin{tabular}{|c|c|c|c|}
\hline P-value & Common & Genbank & Description \\
\hline 0.00168 & HEC & $\mathrm{BC} 035617$ & Highly expressed in cancer \\
\hline 0.00165 & F13A1 & ВC027963 & Coagulation factor XIII, A1 polypeptide \\
\hline 0.00165 & SCGB1D1 & NM_006552 & Secretoglobin, family $1 \mathrm{D}$, member 1 \\
\hline 0.00155 & $\mathrm{DF}$ & NM_001928 & D component of complement (adipsin) \\
\hline 0.00152 & & BC035876 & cDNA FLJ43911 fis, clone TESTI4010928 \\
\hline 0.0015 & SELE & M30640 & Selectin E \\
\hline 0.00146 & NELL2 & D83018 & NEL-like 2 \\
\hline 0.0014 & $\mathrm{EBI} 2$ & BC020752 & Epstein-Barr virus induced gene 2 \\
\hline 0.00138 & DKFZp761P1010 & AL353940 & Hypothetical protein DKFZp761P1010 \\
\hline 0.00135 & SSBP1 & AF277319 & Single-stranded DNA binding protein 1 \\
\hline 0.00125 & NR4A3 & NM_173200 & Nuclear receptor subfamily 4 , group A, member 3 \\
\hline 0.00125 & PIK3R3 & $\mathrm{BC} 021622$ & Phosphoinositide-3-kinase, polypeptide 3 \\
\hline 0.00106 & NR4A1 & BC016147 & Nuclear receptor 4, group A, member 1 \\
\hline 0.00104 & & BC035925 & cDNA clone IMAGE:6150603 \\
\hline 0.00101 & & AK056887 & cDNA FLJ32325, clone PROST2003922. \\
\hline 0.000969 & HIST1H2BG & NM_003518 & Histone $1, \mathrm{H} 2 \mathrm{bg}$ \\
\hline 0.000961 & SOCS3 & AB004904 & Suppressor of cytokine signaling 3 \\
\hline 0.000939 & GSTP1 & BC010915 & Glutathione S-transferase pi \\
\hline 0.000935 & FLJ12960 & NM_024638 & Hypothetical protein FLJ12960 \\
\hline 0.000935 & OSR1 & NM_145260 & Odd-skipped related 1 \\
\hline 0.000917 & SOX17 & AK025905 & SRY (sex determining region Y)-box 17 \\
\hline 0.000888 & BIRC5 & U75285 & Survivin \\
\hline 0.000888 & HIST1H1EH1F4 & M60748 & Histone H1 (H1F4) gene \\
\hline 0.000832 & HIST1H4C & AY128656 & Histone $\mathrm{H} 4$ gene \\
\hline 0.000826 & HIST1H2BG & NM_003522 & Histone $1, \mathrm{H} 2 \mathrm{bg}$ \\
\hline 0.000826 & HIST1H4L & NM_003546 & Histone $1, \mathrm{H} 41$ \\
\hline 0.000776 & CXCL2 & NM_002089 & Chemokine (C-X-C motif) ligand 2 \\
\hline 0.000696 & ACAT2 & NM_005891 & Acetyl-Coenzyme A acetyltransferase 2 \\
\hline 0.000692 & DOCK5 & AK024569 & Dedicator of cytokinesis 5 \\
\hline 0.000668 & E2IG5 & NM_014367 & Growth and transformation-dependent protein \\
\hline 0.000668 & HIST1H1C; H1.2; & X57129 & Histone H1, H1.2 \\
\hline 0.000668 & HSPE1 & $\mathrm{BC} 023518$ & Heat shock $10-\mathrm{kDa}$ protein 1 \\
\hline 0.000668 & MYCBP & BC008686 & c-myc binding protein \\
\hline 0.000668 & PLEK & ВC018549 & Pleckstrin \\
\hline 0.000668 & RPGRIP1 & NM_020366 & Retinitis pigmentosa GTPase interacting protein 1 \\
\hline 0.000648 & LAMB3 & D37766 & Laminin, $\beta 3$ \\
\hline 0.000626 & BEX1 & NM_018476 & Brain expressed, X-linked 1 \\
\hline 0.000626 & EYA2 & NM_172112 & Eyes absent homolog 2 (Drosophila) \\
\hline 0.000626 & SLC6A7 & AK096607 & Solute carrier family 6 , member 7 \\
\hline 0.000619 & C7orf30 & BC012331 & Chromosome 7 open reading frame 30 \\
\hline 0.000603 & CDW52 & ВC000644 & CDW52 antigen (CAMPATH-1 antigen) \\
\hline 0.000569 & EYA2 & NM_172113 & Eyes absent homolog 2 (Drosophila) \\
\hline 0.000556 & CDCA1 & AK093348 & Cell division cycle associated 1 \\
\hline 0.000556 & MGC13057 & BC005083 & Hypothetical protein MGC13057 \\
\hline 0.000547 & $\mathrm{HBB}$ & $\mathrm{BC} 007075$ & Hemoglobin, $\beta$ \\
\hline 0.000525 & CCL2 & M24545 & Chemokine (C-C motif) ligand 2 \\
\hline 0.000525 & CDCA7 & NM_031942 & Cell division cycle associated 7 \\
\hline 0.000525 & DJ79P11.1 & $\mathrm{BC} 015522$ & $\mathrm{X}$-linked protein \\
\hline 0.000525 & HIST1H2BJ & NM_021058 & Histone $1, \mathrm{H} 2 \mathrm{bj}$ \\
\hline 0.000525 & PRSS2 & ВC030260 & Protease, serine, 2 (trypsin 2) \\
\hline 0.000525 & SGNE1 & NM_003020 & Secretory granule, neuroendocrine protein 1 \\
\hline 0.000525 & SYCP2 & ВC040566 & Synaptonemal complex protein 2 \\
\hline
\end{tabular}


Supplementary Table I. Continued.

\begin{tabular}{|c|c|c|c|}
\hline P-value & Common & Genbank & Description \\
\hline 0.000525 & ZNF183 & ВC000266 & Zinc finger protein 183 (RING finger, C3HC4 type) \\
\hline 0.000525 & & & Retired, was Hemoglobin $\alpha 1$ \\
\hline 0.000521 & AHCY & BC011606 & S-adenosylhomocysteine hydrolase \\
\hline 0.000484 & VIP & AY101765 & $\alpha-2$ macroglobulin family protein VIP \\
\hline 0.000468 & HIST1H2BD & NM_021063 & Histone $1, \mathrm{H} 2 \mathrm{bd}$ \\
\hline 0.000468 & SCEL & NM_003843 & Sciellin \\
\hline 0.000464 & FOLR1 & M28099 & Folate receptor 1 (adult) \\
\hline 0.000464 & LDHB & BC015122 & Lactate dehydrogenase B \\
\hline 0.000413 & HBA2 & BC032122 & Hemoglobin, $\alpha 2$ \\
\hline 0.0004 & PURB & AY039216 & Purine-rich element binding protein B \\
\hline 0.000369 & FOSB & NM_006732 & FBJ murine osteosarcoma viral oncogene homolog B \\
\hline 0.000333 & HIST1H4B & NM_003544 & Histone $1, \mathrm{H} 4 \mathrm{~b}$ \\
\hline 0.000331 & BM039 & NM_018455 & Bone marrow protein BM039 \\
\hline 0.000316 & HINT1 & ВC007090 & Histidine triad nucleotide binding protein 1 \\
\hline 0.000316 & XLKD1 & AF118108 & Extracellular link domain containing 1 \\
\hline 0.000316 & ZFP36 & M92843 & Zinc finger protein $36, \mathrm{C} 3 \mathrm{H}$ type, homolog (mouse) \\
\hline 0.000302 & ASRGL1 & ВC021295 & Asparaginase like 1 \\
\hline 0.000302 & MELK & D79997 & Maternal embryonic leucine zipper kinase \\
\hline 0.000302 & MRPS17 & $\mathrm{BC} 047445$ & Mitochondrial ribosomal protein S17 \\
\hline 0.000291 & CKS2 & ВC006458 & CDC28 protein kinase regulatory subunit 2 \\
\hline 0.000291 & $\mathrm{~F} 11 \mathrm{R}$ & NM_144504 & F11 receptor \\
\hline 0.000266 & EGR2 & NM_000399 & Early growth response 2 (Krox-20 homolog, Drosophila) \\
\hline 0.000266 & HIST1H4I & NM_003495 & Histone $1, \mathrm{H} 4 \mathrm{i}$ \\
\hline 0.000266 & SNRPF & $\mathrm{BC} 002505$ & Small nuclear ribonucleoprotein polypeptide $\mathrm{F}$ \\
\hline 0.000244 & Siva & U82938 & Human CD27BP (Siva) mRNA, complete cds. \\
\hline 0.000177 & TACSTD1 & AK026585 & Tumor-associated calcium signal transducer 1 \\
\hline 0.000177 & WAC & ВC004258 & WW domain-containing, with a coiled-coil region \\
\hline 0.000119 & FLJ90586 & NM_153345 & Hypothetical protein FLJ90586 \\
\hline 0.000115 & HBG1; HBGA & ВC020719 & Hemoglobin, $\gamma \mathrm{A}$ \\
\hline 0.000115 & POU5F1 & Z11898 & POU domain, class 5 , transcription factor 1 \\
\hline 0.000115 & RFC5 & ВC001866 & Replication factor C (activator 1) 5 \\
\hline 0.00011 & HIST1H2BC; & BC009612 & Histone $1, \mathrm{H} 2 \mathrm{bc}$ \\
\hline $9,14 \mathrm{E}-05$ & ASNS & ВC014621 & Asparagine synthetase \\
\hline $9,14 \mathrm{E}-05$ & BUB1 & AF046078 & BUB1 budding (yeast) \\
\hline $9,14 \mathrm{E}-05$ & PGRMC1 & Y12711 & Progesterone receptor membrane component 1 \\
\hline $9,14 \mathrm{E}-05$ & TLE4 & AB033087 & Transducin-like enhancer of split 4 [E(sp1) homolog, Drosophila $]$ \\
\hline $8,47 \mathrm{E}-05$ & AD024 & NM_020675 & AD024 protein \\
\hline $8,47 \mathrm{E}-05$ & GPR49 & AF062006 & G protein-coupled receptor 49 \\
\hline $8,47 \mathrm{E}-05$ & $\mathrm{H} 2 \mathrm{AV}$ & ВC000098 & Histone H2A.F/Z variant \\
\hline $3,31 \mathrm{E}-05$ & FLJ14627 & AK094682 & Hypothetical protein FLJ14627 \\
\hline $1,28 \mathrm{E}-05$ & HIST1H3E; H3.1; & AF531278 & histone $\mathrm{H} 3$ \\
\hline $1,28 \mathrm{E}-05$ & PTGDS & AK075333 & Prostaglandin D2 synthase 21-kDa (brain) \\
\hline $1,28 \mathrm{E}-05$ & RAB38 & ВC015808 & RAB38, member RAS oncogene family \\
\hline $1,28 \mathrm{E}-05$ & & ВC042036 & Clone IMAGE:5314816 \\
\hline $1,54 \mathrm{E}-06$ & & NM_152562 & Hypothetical protein FLJ25804 \\
\hline
\end{tabular}

